\title{
Perverse effects of two-tier wage bargaining
}

\section{structures}

\section{Two-tier wage bargaining fails to link wages more closely to productivity and increases allocative inefficiencies}

Keywords: wage drift, favorability principle, productivity-related pay, multi-employer bargaining

\section{ELEVATOR PITCH}

Debate over labor market flexibility focuses mainly on firing costs, while largely ignoring wage determination and the need for collective bargaining reform. Most countries affected by the euro debt crisis have two-tier bargaining structures in which plant-level bargaining supplements national or industrywide (multi-employer) agreements, taking the pay agreement established at the multi-employer level as a floor. Two-tier structures were intended to link pay more closely to productivity and to allow wages to adjust downward during economic downturns, while preventing excessive earning dispersion. However, these structures seem to fail precisely on these grounds.

\section{KEY FINDINGS}

\section{Pros}

๑ In theory, two-tier wage bargaining structures could reconcile macroeconomic stability with a closer link between productivity and pay.

๑ Two-tier bargaining structures may be rationalized as an intermediate step toward greater decentralization in wage setting.

( In theory, the two-tier structure should allow for a higher frequency in wage renegotiation in response to shocks.

( A two-tier structure can work if plant-level bargaining, if any, prevails over the national level, and wage floors are provided by statutory minimum wages.

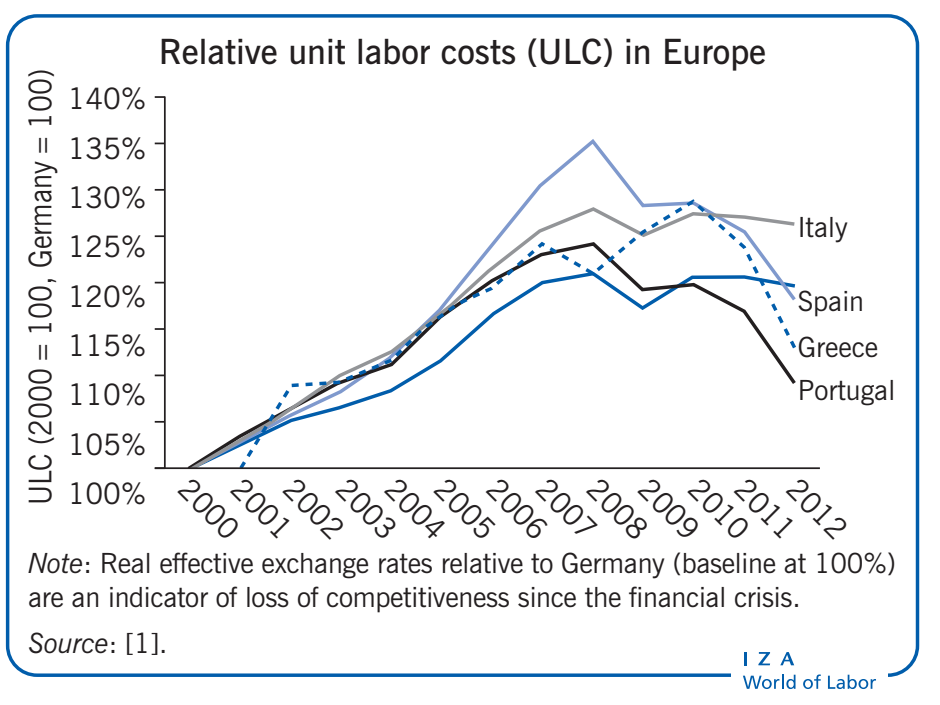

\section{Cons}

- Evidence from a European Central Bank firm-level survey suggests that two-tier regimes may result in the worst of both fully centralized and fully decentralized systems.

- Two-tier systems do not seem to support the expansion of performance-related pay.

- Two-tier systems do not permit adequate adjustment to temporary shocks by cutting wages and hours of work rather than laying off workers.

- Where there are large productivity differentials, twotier systems may reduce nominal wage dispersion but increase real wage dispersion.

\section{AUTHOR'S MAIN MESSAGE}

Two-tier bargaining structures that impose minima set by national bargaining over plant-level negotiations tend to combine the pay rigidity of centralized systems with the inattention to macroeconomic constraints of decentralized systems. Unfolding two-tier regimes into stand-alone plant-level bargaining and centralized agreements for other firms could offer a better way to reconcile microeconomic flexibility with macroeconomic stability. The multi-employer agreements should impose wage rules rather than wage levels to be applied uniformly to all firms, regardless of performance. And wage floors should be provided by statutory minimum wages not by centralized bargaining. 


\section{MOTIVATION}

Two-tier bargaining structures such as those prevailing in the countries affected by the eurozone crisis are claimed to be responsible for the loss of competitiveness of these countries, as documented by their real effective exchange rate appreciation relative to Germany in the last 15 years (see illustration on p.1). Based on findings such as these, the European Commission, European Central Bank, and International Monetary Fund (the so-called Troika) have been requesting reforms to collective bargaining structures as a condition for providing external assistance. Surprisingly enough, the same multilateral organizations now pushing for reforms of bargaining systems had previously praised the introduction of these two-tier structures as a way to reconcile macroeconomic stability with some microeconomic flexibility in wage setting, enabling a closer link between productivity and pay.

In these bargaining structures, multi-employer wage agreements (at the national, industry, or regional levels) coexist with plant- or firm-level, single-employer negotiations over a wide array of issues, including pay levels. There is, however, a hierarchy in these structures, brought about as a result of opposition by labor unions to a fully decentralized system and resistance by employers' associations, dominated by large firms, to more competition in wage setting. The result is a sort of "controlled decentralization," in which the national wage agreement dominates wage-setting at the local level. Wage floors are imposed on lower level bargaining by the multi-employer agreements according to the so-called "favorability principle," which prevents plant-level agreements from making workers worse off than they are under the higher level bargaining (in peius).

What could explain such a sea change in recommendations by lending institutions and multilateral organizations? Did two-tier bargaining structures fail to do what they were expected to do? If so, was it because they failed to deliver macroeconomic stability or the microeconomic flexibility they were supposed to achieve?

While much work has been done in analyzing the different effects on wages, employment, and earning differentials of centralized and decentralized bargaining structures, much less is known about the properties of the two-tier structures. Drawing on data from a cross-country survey coordinated by the European Central Bank, it is possible to fill in some of the gaps and shed light on the performance of two-tier bargaining relative to either fully centralized or fully decentralized systems, all the while acknowledging the heterogeneity of bargaining regimes in different countries.

\section{DISCUSSION OF PROS AND CONS}

The general structure of two-tier bargaining is one in which the higher level of bargaining dominates, leaving to plant-level bargaining only the ability to influence wages through "wage drift" with respect to wages at the national or industry level. Sometimes this

\section{Wage drift}

Wage drift refers to the increase in worker compensation negotiated at the single plant (or firm) level relative to the level decided at the multi-employer (national, industrywide, or regional) level. 
favorability principle extends to issues beyond wages and encompasses other standards determined at a higher level, such as hours of work and annual leave, and these terms too can only be improved (from the employees' perspective) but not worsened at the lower level.

Beginning in the 1990s, a large number of countries began to adopt two-tier bargaining structures or to extend the scope of two-tier structures that were already in place. For instance, in Denmark the proportion of firms carrying out two-tier bargaining more than doubled between 1989 and 1995, with industry-level collective bargaining agreements fixing the minimum wage and plant-level negotiations raising the levels. Belgium experienced a similar expansion. While two-tier structures were already in place in Belgium during the 1970s, they were quite limited in scope. Then, from 1980 to the mid-1990s, the number of firms involved in both industry- and plant-level agreements increased tenfold [2]. Two-tier bargaining structures were also in place in Austria, Finland, Italy, the Netherlands, Norway, and Sweden by the turn of the 21st century [3], [4]. More recently, Portugal and Spain have joined this movement, although decentralization has never been as organized there as in the countries where two-tier systems have a longer tradition [5].

Although the history and design of these structures differ considerably from country to country, a common impetus behind their development was the search for an organized or controlled form of decentralized collective bargaining. The so-called "social partners," rather than moving from fully centralized to fully decentralized structures, opted for operating somewhere in the middle.

Three key forces played an important role in the shift toward greater decentralization and the emergence of two-tier structures. The first was globalization and import competition by goods from low-labor-cost countries that eroded the rents that could be shared at the bargaining table. Globalization also increased the employment bias of centralized wage setting, since plant-level employment levels cannot be negotiated under higherlevel centralized bargaining. A second factor was the unbundling of production along the value chain, with large firms optimizing production on a plant by plant basis, which requires negotiating all aspects of production simultaneously. The third factor, which applies only to eurozone countries, was the introduction of the common currency, which de facto decentralized even the most centralized wage structures by depriving national agreements of any agent who could make credible commitments to a targeted inflation rate [1].

\section{Where do two-tier bargaining structures exist?}

Most studies on collective bargaining look solely at aggregate figures of coverage at different bargaining levels, without considering the nature of the participants in these bargaining structures. The European Central Bank's Wage Dynamics Network survey, an ad hoc survey on wage and pricing policies at the firm level in the EU, collects some information on bargaining structures at large and middle-size firms. Only cross-section data for 2007-2009, covering 13 countries (Austria, Czech Republic, Estonia, France, Greece, Hungary, Italy, Ireland, Lithuania, the Netherlands, Portugal, Slovenia, and Spain) are currently available to researchers. 


\section{The coverage of collective bargaining}

The coverage of collective bargaining refers to the percentage of the eligible workforceemployees with bargaining rights-whose contract is regulated by the relevant collective agreement. It often exceeds the union density rate, that is, the fraction of workers who are members of trade unions. In this case, reference is made to the excess coverage of collective bargaining.

The survey data suggest that at the outset of the Great Recession two-tier bargaining was particularly relevant in France, Greece, Italy, Spain, and Portugal, where, on average, about $90 \%$ of employers reported that they were constrained in making downward wage adjustment by higher-level, multi-employer collective wage agreements. Between $6.7 \%$ and $44.2 \%$ of firms carry out plant-level bargaining on top of multi-employer agreements [1]. In other words, there was no stand-alone plant-level bargaining in these countries at the time of the survey. This possibility was introduced recently in Greece (2011), Portugal (2011), and Spain (2012) under conditions set by the Troika, while France and Italy recently increased the scope for exemptions from national collective bargaining agreements to allow lower-level agreements that may worsen the position of workers (for example, by lowering wages with respect to levels set under multi-employer agreements).

What kinds of firms carry out plant-level bargaining on top of multi-employer agreements in these countries? As suggested by Figure 1, these firms are larger than the typical business unit, probably because small firms are either not unionized or the unions are not strong enough to impose a second level of bargaining that improves on the national or industry-level wage agreements. This size effect may also explain why plant-

Figure 1. Coverage of plant-level bargaining in two-tier systems varies by firm size, (2007-2009

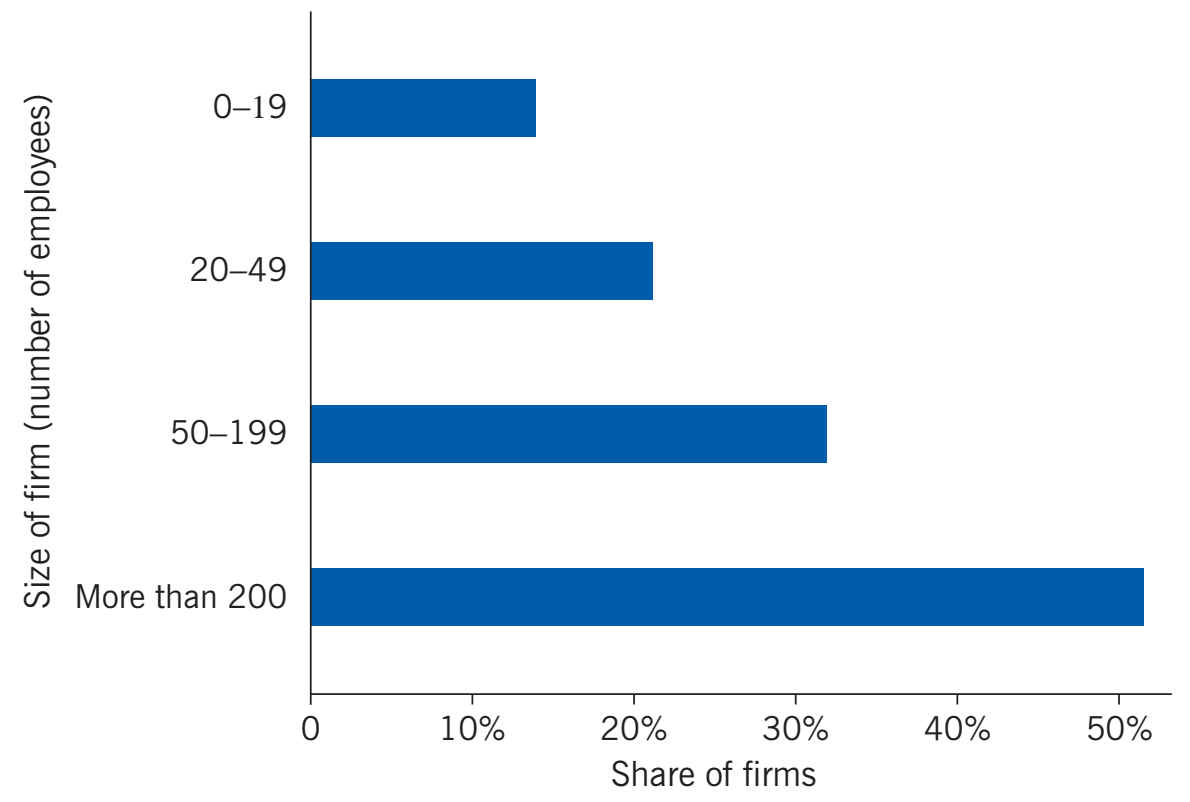

Source: Boeri, T. Two-Tier Bargaining. IZA Discussion Paper 8358, July 2014. Online at:

http://ftp.iza.org/dp8358.pdf [1]. 
level bargaining agreements are concentrated in energy and manufacturing (Figure 2). Employers obviously have no incentive to sit at a decentralized bargaining table when the outcome can only add to the wage scale already imposed by higher levels of bargaining. True, in some cases a claim can be made that a reduction in pay compared with the national or industry-level agreement can support the interests of the workers involved (satisfying the favorability principle), but it is always a risky proposition for employers of firms that are not close to bankruptcy to challenge contractual minima imposed by higher bargaining levels.

Figure 2. Coverage of plant-level bargaining in two-tier systems also varies by firm (sector, 2007-2009

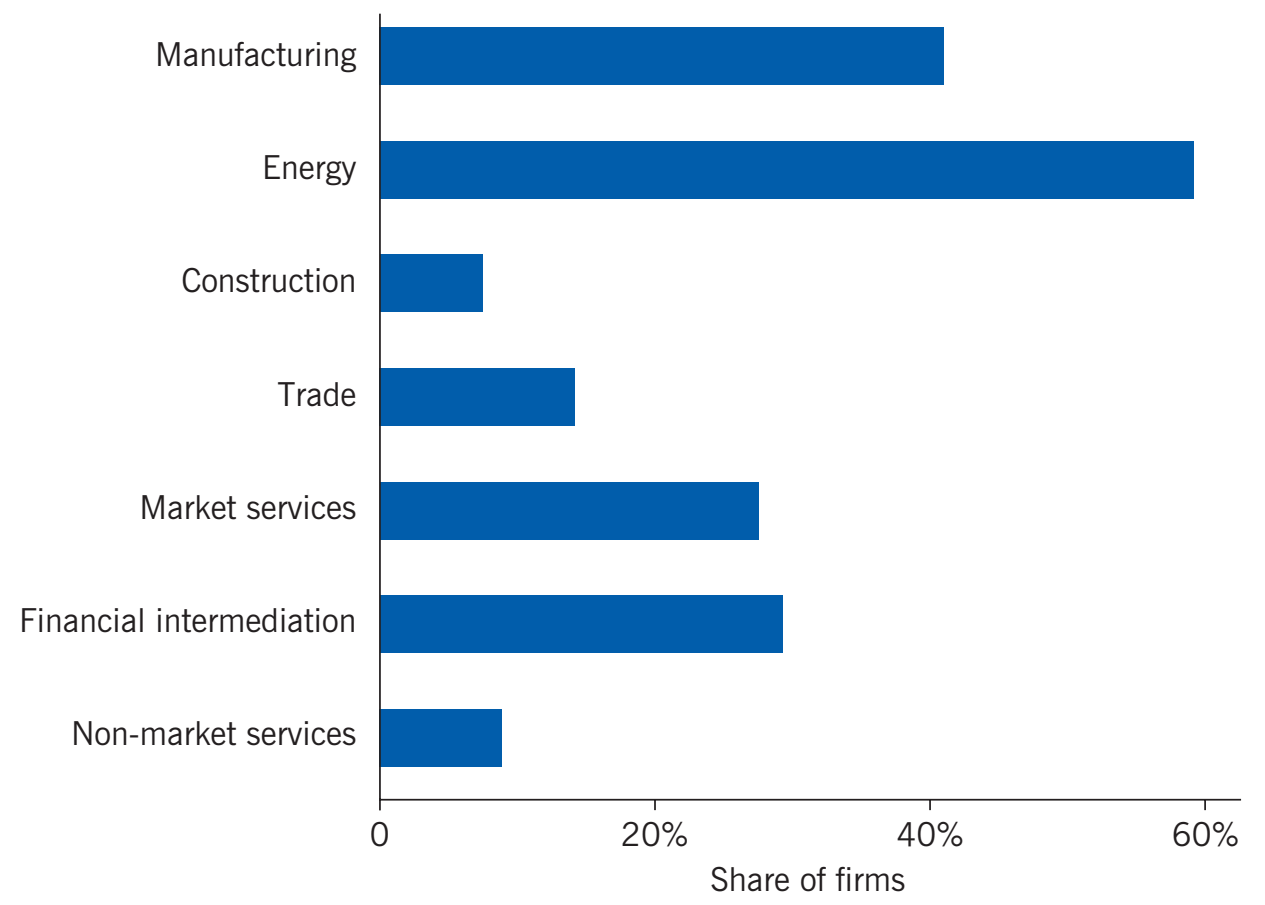

Source: Boeri, T. Two-Tier Bargaining. IZA Discussion Paper 8358, July 2014. Online at: http://ftp.iza.org/dp8358.pdf [1].

\section{Behavior during the Great Recession}

In the Wage Dynamics Network survey, which in most countries was carried out at the beginning of the Great Recession of 2008-2009, firms were asked how they would reduce labor costs, whether by cutting hours, wages (either the base wage or bonuses), or employment (either temporary contracts or permanent contracts). The responses indicate that firms carrying out plant-level bargaining within two-tier bargaining systems do not behave much differently from firms whose employers confine themselves to applying national or industry agreements without further bargaining at the decentralized level.

The firms applying plant-level agreements on top of multi-employer agreements adjust employment more than wages or hours in response to adverse shocks, unlike firms that have no collective bargaining at all. In particular, about $60 \%$ of firms involved in two- 
tier bargaining adjust mainly employment, just like firms involved only in multi-employer bargaining. By contrast, firms where bargaining presumably takes place only at the individual firm level adjust mainly wages in response to adverse shocks (Figure 3) [1]. These findings, which are robust to controls for country, industry, and size of firms, suggest that plant-level bargaining in two-tier regimes is inefficient in that it does not allow wage concessions to be traded for employment security, as in the case of standalone plant-level bargaining.

\section{Efficient bargaining}

Efficient bargaining can be carried out only at the level of the individual firm (plant) as it involves setting both wages and employment levels.

Figure 3. Strategies to cut costs vary by bargaining level, 2007-2009 (percentage of firms)

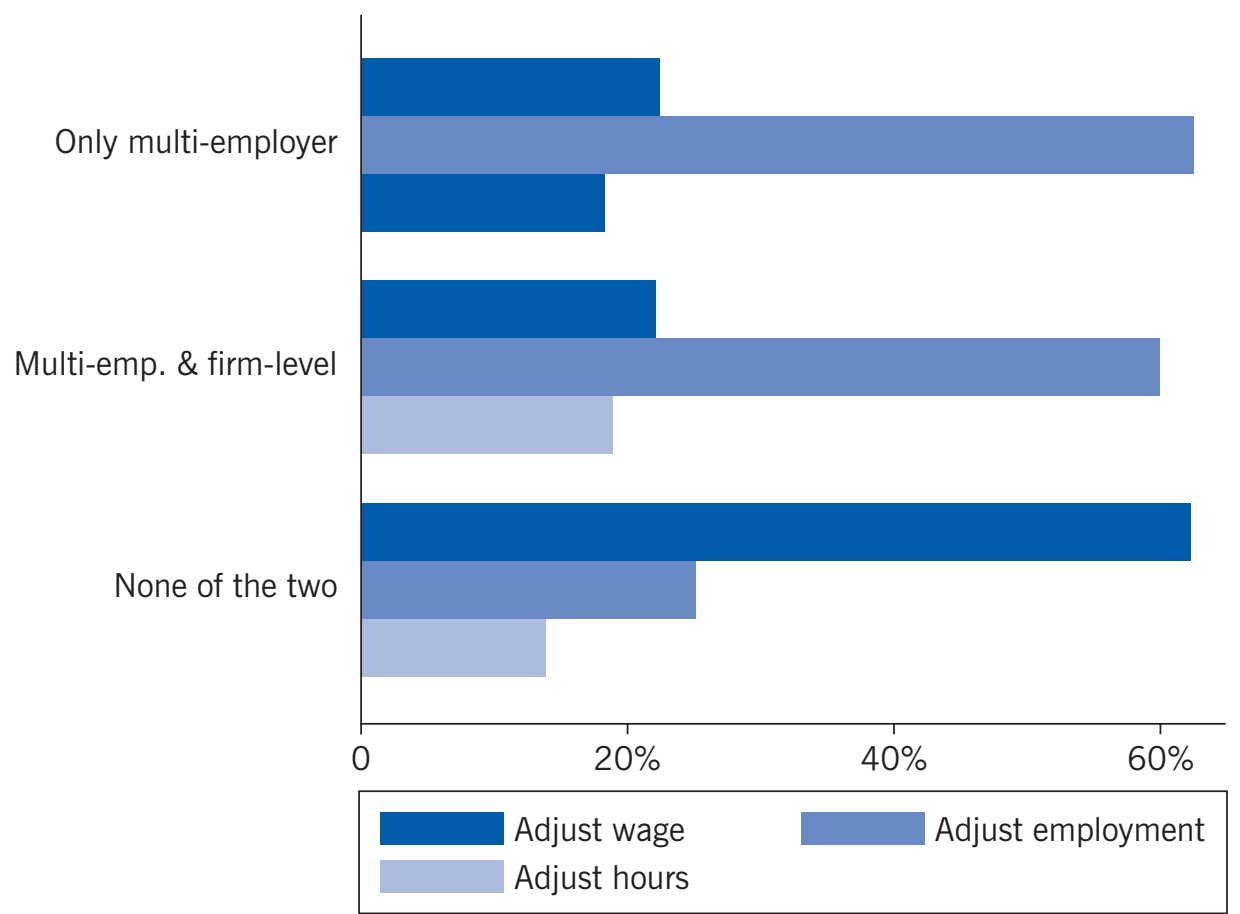

Source: Boeri, T. Two-Tier Bargaining. IZA Discussion Paper 8358, July 2014. Online at: http://ftp.iza.org/dp8358.pdf [1].

The issue is that in plant-level negotiations in two-tier bargaining, wages can be adjusted only above the wage floor imposed by the multi-employer bargaining agreements. This constraint prevents lower level negotiations from agreeing to wages that are below the level established at the national, industry, or regional level. This constraint clearly reduces the scope for plant-level bargaining by shrinking the relevant range of bargaining outcomes in which wage concessions can be traded for employment concessions at the plant level. If the wage floor is sufficiently high, plant-level bargaining can improve the situation of only one party to the negotiations, the unions, while making the employer 
worse off. If the plant-level union is sufficiently strong, it may force the employer to increase employment without cutting wages, causing profits to decline. Otherwise, plant-level negotiations will not depart from the outcomes of higher (multi-employer) bargaining levels.

Put differently, there are no efficiency gains in moving from a centralized to a two-tier bargaining regime, as the lower bargaining level cannot truly bargain over wages and thus cannot achieve the types of outcomes posited in the literature for decentralized outcomes [6], [7], [8], which feature lower wages and higher employment than the socalled right-to-manage outcomes of multi-employer bargaining over wages only. Similarly, wage floors imposed by multi-employer bargaining prevent decentralized bargaining from achieving outcomes that could help reduce gross job destruction during times of temporary negative shocks by allowing for cost reductions along the intensive margin through adjustment of hours. That is because the wage floors prevent tradeoffs between reductions in hours and monthly wages and employment concessions [9].

\section{Right-to-manage}

Under right-to-manage, wage bargaining is typically carried out at the multi-employer level, while employment levels are set by employers of individual firms or plants.

\section{Incidence of performance-related pay}

A key argument made for the introduction of two-tier bargaining structures was that they would allow pay and productivity to be linked more closely than is the case under pure multi-employer bargaining. The European Central Bank's Wage Dynamics Network survey data suggest that more firms that are subject to both levels of bargaining use performance-related pay practices than do firms subject only to multi-employer bargaining (Figure 4). However, the part of the wage bill that is affected by remuneration components that are linked to an individual's performance is no greater in firms that are engaged in both levels of bargaining than it is in firms that apply only higher-level agreements. Moreover, both the extensive component of productivity-related pay (fraction of firms using performance-related pay) and the intensive component (fraction of the wage affected by performance-related pay) are higher in firms applying standalone agreements.

These findings are quite striking, as two-tier regimes were, at least in principle, introduced to link productivity and pay more closely. The relatively low share of performance-related pay in overall pay in the firms engaged in two-tier bargaining may have to do with the presence of wage floors imposed by multi-employer bargaining in the two-tier structures, so that wages can be increased only over an already relatively high wage floor.

Performance-related pay cannot operate properly as an incentive device under these conditions, because employers will try to contain the potential wage drift associated with the second level of bargaining. Also working against a closer link between productivity and pay in firms under two-tier bargaining regimes is the fact that plant-level agreements in two-tier structures typically occur less frequently than industry-level agreements [10]. 
Figure 4. Two-tier structures do not provide more performance-related pay than other collective bargaining regimes (\%)

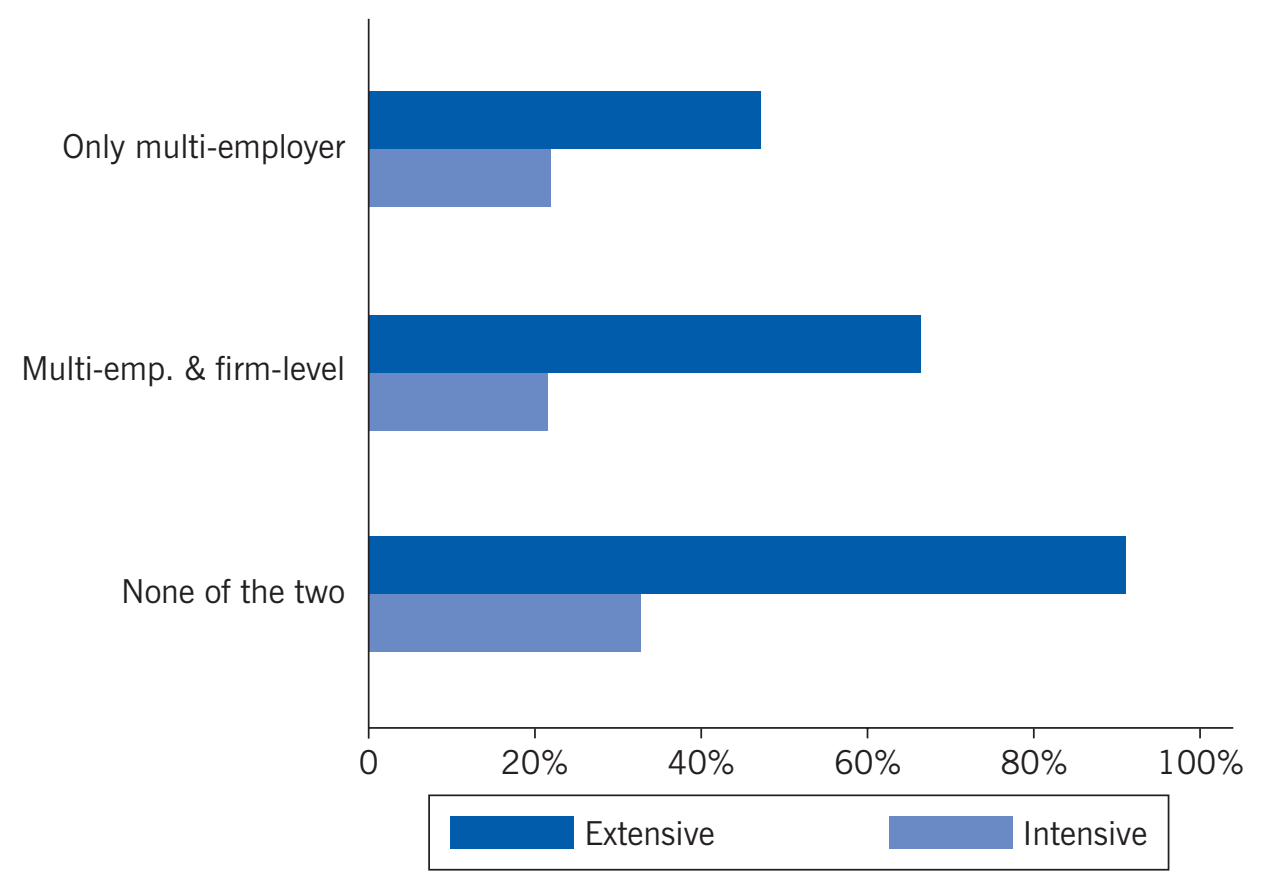

Note: Extensive refers to the fraction of firms applying performance-related pay, and intensive refers to the fraction of the wage affected by performance-related pay.

Source: Boeri, T. Two-Tier Bargaining. IZA Discussion Paper 8358, July 2014. Online at: http://ftp.iza.org/dp8358.pdf [1].

This prevents linking productivity and pay more closely by adjusting remuneration to changes in the business environment faced by firms.

\section{Wage differentials and two-tier regimes}

A final argument that is usually made in favor of two-tier bargaining structures over fully decentralized wage structures is that the two-tier structures prevent the rapid spread of wage inequalities. According to Richard Freeman, in particular, "if you want to increase inequality, you must weaken centralized collective bargaining" [11]. However, the compression of nominal wage disparities does not necessarily imply a reduction in real wage inequality, notably in countries with large productivity differentials across firms and regions. Where wage structures are compressed, such productivity differentials generate large differences in unemployment and housing costs across regions. The wage structure is then distorted as workers move from low-productivity and high-unemployment areas to high-productivity and low-unemployment areas, boosting residential costs in the new area and thus reducing real wages. When workers' living standards are properly measured, it turns out that real wage dispersion may be even larger in countries with centralized wage structures than in countries without them [12]. Even more important, such inequalities in real wages are associated with large efficiency losses, as they lead to increased unemployment and reduced output by rewarding low-productivity workers and preventing more and better quality jobs from being created in high-productivity firms. 


\section{LIMITATIONS AND GAPS}

Firms are not randomly allocated across different bargaining regimes. Hence, the associations that are observed between bargaining regimes and firms' adjustment to shocks and the extent of performance-related pay can be interpreted only as correlations. However, the findings are robust to controls for the factors that are likely to play a key role in the sorting of firms across bargaining regimes (country, industry, and size). To identify a causal effect of the bargaining structure on a firm's adjustment to shocks and the extent of performance-related pay would ideally require combining cross-sectional data and time series observations on firms and identifying the effects of two-tier bargaining by exploiting some exogenous variation in the bargaining regime.

\section{SUMMARY AND POLICY ADVICE}

Overall, the case for two-tier bargaining is not very strong, but the reasons are only partly related to external competitiveness. The real issue is that these structures do not allow for the microeconomic flexibility in wage setting, employment, and hours adjustment that they were supposed to achieve, and they do not seem to enhance productivityrelated pay.

A better design for collective bargaining might be a structure in which plant-level bargaining, wherever it occurs, prevails over higher bargaining levels and where industrylevel or national bargaining holds only on a subsidiary basis-that is, where it is limited to firms that do not engage in collective bargaining at the plant level. Excessive wage inequality associated with monopsonistic power of employers can be reduced, in this context, by statutory minimum wages that are set at a level that does not have strong negative effects on employment.

Compressing nominal wage structures through national agreements may instead distort incentives, increase unemployment, and paradoxically increase the dispersion of living standards among workers. It is better that national agreements specify wage rules, rather than wage levels, allowing wages to differ according to performance in each individual firm.

\section{Acknowledgments}

The author thanks an anonymous referee and the IZA World of Labor editors for many helpful suggestions on an earlier draft. This paper draws on many of the findings in [1].

\section{Competing interests}

The IZA World of Labor project is committed to the IZA Guiding Principles of Research Integrity. The author declares to have observed these principles.

(c) Tito Boeri 


\section{REFERENCES}

\section{Further reading}

Boeri, T., C. Lucifora, and K. Murphy. Executive Remuneration and Employee Performance Related Pay, A Transatlantic Perspective. Oxford, UK: Oxford University Press, 2013.

Cardoso, A., and P. Portugal. "Contractual wages and the wage cushion under different bargaining settings." Journal of Labor Economics 23:4 (2005): 875-902.

Driffill, J. "The centralization of wage bargaining revisited: What have we learnt?" Journal of Common Market Studies 44:4 (2006): 731-756.

\section{Key references}

[1] Boeri, T. Two-Tier Bargaining. IZA Discussion Paper 8358, July 2014. Online at: http://ftp.iza.org/ dp8358.pdf

[2] van Ruysseveldt, J., and J. Visser. Industrial Relations in Europe: Traditions and Transitions. London, UK: Sage Publications, 1996.

[3] Holden, S. "Wage drift and the relevance of centralised wage setting." The Scandinavian Journal of Economics 100:4 (1998): 711-731.

[4] Boeri, T., A. Brugiavini, and L. Calmfors. The Role of Unions in the Twenty-first Century: A Report for the Fondazione Rodolfo Debenedetti. Oxford, UK: Oxford University Press, 2001.

[5] Catalan, L. D., and E. Villanueva. "Collective Bargaining and Unemployment during the Great Recession: Evidence from Spain.” Paper presented at the IZA Workshop on Wage Rigidities and the Business Cycle: Causes and Consequences, Bonn, June 9-10, 2014. Online at: http://www. iza.org/conference_files/wagerigidities_2014/villanueva_e7178.pdf

[6] McDonald, I. M., and R. M. Solow. "Wage bargaining and employment." The American Economic Review 71:5 (1981): 896-908.

[7] MaCurdy, T. E., and J. Pencavel. "Testing between competing models of wage and employment determination in unionized markets." Journal of Political Economy 94:3 (1986): S3-S9.

[8] Brown, J. N., and O. C. Ashenfelter. "Testing the efficiency of employment contracts." Journal of Political Economy 94:3 (1986): S41-S87.

[9] Jimeno, J. F., and C. Thomas. "Collective bargaining, firm heterogeneity, and unemployment." European Economic Review 59:C (2013): 63-79.

[10] Avouyi-Dovi, S., D. Fougère, and E. Gautier. "Wage rigidity, collective bargaining, and the minimum wage: Evidence from French agreement data." The Review of Economics and Statistics 95:4 (2013): 1337-1351.

[11] Freeman, R. "Saving Europe's collective bargaining model to improve economic stability and curtail inequality before the next Armageddon." Presentation at the International Monetary Fund-International Trade Union Confederation Workshop on Collective Bargaining, Washington, DC, June 18, 2014.

[12] Boeri, T., A. Ichino, and E. Moretti. "Unintended consequences of wage equality across regions." Manuscript, Milan, 2014.

The full reference list for this article is available from the IZA World of Labor website (http://wol.iza.org/articles/perverse-effects-of-two-tier-wage-bargaining-structures). 